\title{
Effect of short-term naturopathy and yoga intervention on anthropometric variables, lipid profile and thyroid profile in obese hypothyroid patients: a randomised controlled trial
}

\author{
Geetha B. Shetty ${ }^{1 *}$, Balakrishna Shetty ${ }^{2}$, Prashanth Shetty ${ }^{3}$
}

\begin{abstract}
${ }^{1}$ Department of Physical Therapeutics and Nutrition, ${ }^{2}$ Department of Biochemistry, SDM College of Naturopathy and Yogic Sciences, Ujire, Karnataka, India

${ }^{3}$ Principal, SDM College of Naturopathy and Yogic Sciences, Ujire, Karnataka, India
\end{abstract}

Received: 05 January 2020

Revised: 20 January 2020

Accepted: 21 January 2020

*Correspondence:

Dr. Geetha B. Shetty,

Email: gbsujire@gmail.com

Copyright: () the author(s), publisher and licensee Medip Academy. This is an open-access article distributed under the terms of the Creative Commons Attribution Non-Commercial License, which permits unrestricted non-commercial use, distribution, and reproduction in any medium, provided the original work is properly cited.

\section{ABSTRACT}

Background: Hypothyroidism reflects decreased thyroid function and is one of the most common conditions seen in clinical practice. Practice of naturopathy and yoga has shown improvement in anthropometric variables and lipid profile in obesity and other chronic diseases. So, the aim of this study was to find out the effect of naturopathy and yoga in obese hypothyroid patients.

Methods: A total of 60 subjects, of which 29 males (age $44.2 \pm 7.0$ years) and 31 females (age $40.6 \pm 7.4$ years) with body mass index $(B M I), \geq 30$ were randomly assigned to case group $(n=30)$ and wait list control group $(n=30)$. The subjects of case group underwent naturopathy and yoga intervention for 10 days. Anthropometric variables, viz., body weight, BMI, waist circumference (WC) and hip circumference, serum lipid profile, and serum thyroid profile were assessed at $1^{\text {st }}$ day (pre), at the end of 10 day (post).

Results: The result showed a significant reduction in body weight, BMI, WC, total cholesterol, low density lipoprotein-cholesterol (LDL-C) and thyroid stimulating hormone (TSH) along with significant improvement in high density lipoprotein-cholesterol (HDL-C) in case group compared with control group in independent samples t test. Significant reduction in body weight, BMI, total cholesterol, LDL-C and TSH were observed in case group unlike in control group in student's paired t test.

Conclusions: Reduction in the body weight, BMI and improvement in serum lipid profile and serum thyroid profile in case group subjects compared to control group suggest that naturopathy and yoga have therapeutic and protective effects in the management of obese hypothyroid patients.

Keywords: Hypothyroid, Obesity, Naturopathy, Yoga, Lipid profile, Thyroid profile

\section{INTRODUCTION}

Hypothyroidism is a common endocrine disorder resulting from deficiency of thyroid hormone or, more rarely, from their impaired activity at tissue level. ${ }^{1}$ It is believed to be a common health issue in India and worldwide. The prevalence of hypothyroidism is quite high, affecting approximately one in 10 out of 35 adults. $^{2}$ It is more prevalent in females and elder population. ${ }^{3}$ One of the preventable measures for hypothyroidism is adequate iodine intake especially for those who suffer from hypothyroidism due to iodine deficiency. In general, India is now considered to be in the post-iodization 
phase; even then the prevalence of hypothyroidism is not diminished. ${ }^{4}$

Thyroid dysfunction is associated with changes in body weight and composition, body temperature, and total and resting energy expenditure because triiodothyronine $\left(\mathrm{T}_{3}\right)$ regulates energy metabolism and thermogenesis and plays a critical role in glucose and lipid metabolism, food intake, and the oxidation of fatty acids. ${ }^{5}$ Both subclinical and overt hypothyroidism is frequently associated with weight gain, decreased thermogenesis, and metabolic rate. ${ }^{6,7}$ In a recent cross-sectional, population-based study has shown correlation between subclinical and overt hypothyroidism with a higher body mass index (BMI) and a higher prevalence of obesity. ${ }^{7}$ It has been noted that small variations in serum thyroid stimulating hormone (TSH) caused by minimal changes in levothyroxine (L$\mathrm{T}_{4}$ ) dosage during replacement therapy are associated with significantly altered resting energy expenditure in hypothyroid patients. ${ }^{8}$ These studies support the clinical evidence that mild thyroid dysfunction is linked to significant changes in body weight and likely represents a risk factor for overweight and obesity. Hypothyroidism is characterized by increased level of TSH, triglycerides and low-density lipoprotein-cholesterol (LDL-C). ${ }^{9,10}$ Hence patients who have hypothyroidism are associated with the increased risk of cardiovascular disease, weight gain and dyslipidemia.

Naturopathy and yoga are popular complementary and alternative medicine (CAM) therapies being increasingly used for the prevention and management of noncommunicable diseases across the world. Naturopathy is a system of man building in harmony with the constructive principles of Nature on the physical, mental, moral and spiritual planes of being and consists of noninvasive treatment modalities like diet therapy, fasting therapy, massage therapy, hydrotherapy, mud therapy, chromotherapy and magnetotherapy. ${ }^{11,12}$ Earlier studies have shown significant reduction in body weight, total cholesterol, triglycerides, LDL-C and oxidative stress in various clinical conditions viz., type II diabetes mellitus, obesity, hypertension, cardiovascular diseases and end stage renal disease by lifestyle modification and adopting naturopathy and yoga based practices. ${ }^{13-15}$

Yoga is a form of mind-body medicine that involves a combination of muscular activity and an internally directed mindful focus on awareness of the self, the breath, and energy and now it is classified by the National Institutes of Health as a form of CAM. ${ }^{16} \mathrm{~A}$ typical yoga practice includes physical postures (asanas), voluntarily regulated breathing techniques (pranayamas), meditation, and certain philosophical principles. ${ }^{17}$ Practicing yoga resulted in a significant reduction in BMI, glycemic control, and increase in glutathione, and vitamin $\mathrm{C}$ in persons with type 2 diabetes mellitus. ${ }^{14}$ There was a decrease in body fat $\%$, total cholesterol, triglycerides, and LDC-C, as well as systolic blood pressure, diastolic blood pressure and heart rate in subjects with the coronary artery disease following yoga practice. ${ }^{18}$ So yoga may be beneficial in the management of hypothyroidism as it is associated with hyperlipidemia. Hence, in the present study, we aimed to see the effect of naturopathy and yoga based life style in the management of obese hypothyroidism and its associated complications.

\section{METHODS}

\section{Subjects}

A total of 60 (29 male) pre diagnosed obese hypothyroid patients, with $\mathrm{BMI} \geq 30 \mathrm{~kg} / \mathrm{m}^{2}$ were recruited for the study. Those subjects with TSH $<5 \mathrm{mU} / \mathrm{l}$, and BMI $\geq 30$ $\mathrm{kg} / \mathrm{m}^{2}$ and ages ranged between 30 and 50 years (group mean \pm SD, $42.4 \pm 7.4$ years) were included for the study and subjects with a history of any systemic diseases, on regular medication for any disease and who were practically unable to perform yoga and physical activity were excluded from the study. The sample size was determined based on the number of subjects who voluntarily participated in the trial. There was no attempt to determine the sample size based on previous effect sizes, which is a limitation of our study. The study was conducted in SDM yoga and nature cure hospital, Shantivana from July 2016 to August 2018. Study protocol was approved by the institutional ethics committee (Reg. No.: EC-136), and written informed consent was obtained from the participants.

Baseline assessments (pre-test) were performed on 60 subjects, 30 each in study group and control group on the day prior to their intervention. Post data assessments (post-test) were performed at the end of $10^{\text {th }}$ day.

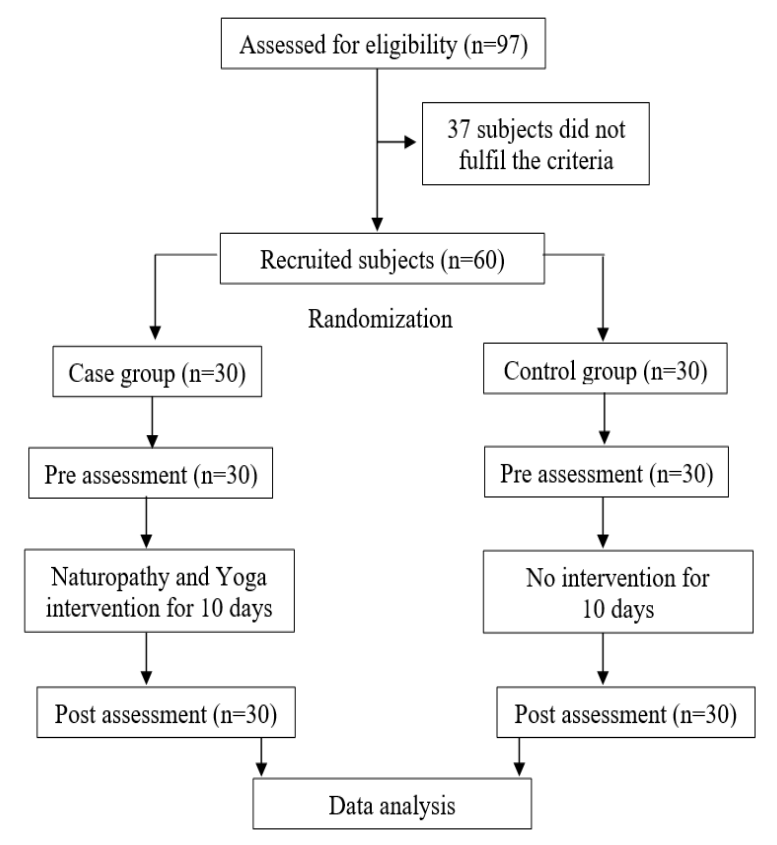

Figure 1: Trial profile of the study. 


\section{Randomization}

The recruited subjects were randomized into either study or control group on the day prior to their intervention using the papers with word "study" and "control" were put in an envelope and the paper each subject drew out determined their group. Through this method of randomization both groups were allocated 30 participants each. The randomization was done by one of the authors who was involved in the intervention, but he did not involve himself in any part of the investigation.

\section{Blinding/masking}

It was not possible to mask the naturopathy and yoga intervention from the subjects. However, the investigator who did the assessment were blind to the intervention or study group/control group.

\section{Assessments}

The participants were assessed for anthropometric variables, viz., body weight, BMI, waist circumference (WC) and hip circumference (HC), serum lipid profile and thyroid profile.

All anthropometric measurements were performed by one investigator. Body weight was measured using an electronic scale (ESSAE, EEROKA LTD, India) to the nearest $0.1 \mathrm{~kg}$, with the subjects wearing light clothing and no shoes. Height was measured to the nearest $0.5 \mathrm{~cm}$ without shoes, and BMI was calculated as weight (in kilograms) divided by the square of height (in meters). Waist circumference was measured with a horizontal tape midway between the lower rib margin and iliac crest, at the end of gentle expiration. Hip circumference was measured around the widest portion of the buttocks, with the measuring tape parallel to the floor. For both measurements, the individuals were made to stand with their feet close together, arms at the sides, and body weight evenly distributed, and in little clothing. The subjects were relaxed, and the measurements were taken at the end of a normal expiration. ${ }^{19}$

For biochemical estimations, about $5 \mathrm{ml}$ of venous blood was collected from all the participants and the serum was used. All the biochemical investigations were carried out in a fully automated biochemistry analyzer (ERBA-EM 200). The study variables were assessed at $1^{\text {st }}$ day (pretest) and at the end of $10^{\text {th }}$ day (post-test) of study period.

\section{Intervention}

The subjects of the study group underwent 10 days of naturopathic and yogic interventions. Naturopathic treatments included hydrotherapy, mud therapy, fasting therapy and diet modification. The yogic intervention was a 50 minutes yoga session per day for 10 days which included asanas, pranayama and relaxation techniques given in Table 1. The subjects of control group did not receive naturopathy and yoga intervention and continued with their normal routines during the study period.

\section{Data analysis}

The results are expressed as the mean \pm SD. Data were checked for normality using the Kolmogorov-Smirnov test. Statistical analysis between groups was performed using independent samples t test and within groups was analysed using paired samples $t$ test. Level of significance in the present study was $\mathrm{p}$ value $<0.05$. Data were analysed using IBM SPSS Statistics (Version 19.0.0) software package.

\section{RESULTS}

A total of 97 pre diagnosed obese hypothyroid subjects were assessed for the eligibility, based on the study's inclusion and exclusion criteria. Out of which 37 subjects did not fulfil the criteria and were not included in the study. The recruited 60 subject's baseline assessment was taken before intervention. All the participants $(n=60)$ completed the study successfully and post assessment was done after the intervention. Table 2 shows the baseline comparison of study variables of study group and control group.

Analysis of the difference between the pre and the post of the study group vs. between the pre and the post of control were done by using independent samples t test and within the group pre- and post-assessment of study and control were done by using Student's paired t test.

The results of the present study showed significant decreases in body weight, BMI, WC, triglycerides, total cholesterol, LDL-cholesterol and TSH and significant increase in HDL-cholesterol in the study group compared with the control group, but no significant changes were found between the groups in the rest of the variables in independent samples t test (Table 3).

The student paired t test was used to find the changes in the pre- and post-intervention outcome of within the groups. It showed significant decreases in the anthropometric variables i.e., body weight, and BMI of study group, but in control group no such changes were found WC and HC were insignificantly reduced in both study group and control group (Table 4).

Significant decrease in triglycerides, total cholesterol and LDL-cholesterol were found in the study group compared to the control group. But significant changes were not observed in lipid profile variables in the control group. The results of the study showed significant decrease in TSH of study group, but in control group no such changes were found. No significant changes were found in $\mathrm{T}_{3}$ and $\mathrm{T}_{4}$ in study and control group. 
Table 1: Details of naturopathy and yoga intervention provided to the study participants during study period.

\begin{tabular}{|c|c|c|c|}
\hline Therapy & Specific treatment & $\begin{array}{l}\text { Duration/ } \\
\text { session } \\
\text { (min) }\end{array}$ & $\begin{array}{l}\text { Total number of } \\
\text { sessions/10 days }\end{array}$ \\
\hline \multirow{9}{*}{ Hydrotherapy } & Cold throat pack $\left(12^{\circ}-18^{\circ} \mathrm{C}\right)$ & 20 & 10 \\
\hline & Cold hip Bath $\left(12^{\circ}-18^{\circ} \mathrm{C}\right)$ & $15-20$ & 3 \\
\hline & Sauna bath & $10-15$ & 1 \\
\hline & Steam bath & $10-15$ & 2 \\
\hline & Cold under water massage $\left(12^{\circ}-18^{\circ} \mathrm{C}\right)$ & $15-20$ & 3 \\
\hline & Cold douche to whole body $\left(12^{\circ}-18^{\circ} \mathrm{C}\right)$ & 10 & 3 \\
\hline & Cold immersion bath with friction $\left(12^{\circ}-18^{\circ} \mathrm{C}\right)$ & $15-20$ & 3 \\
\hline & Cold circular jet $\left(12^{\circ}-18^{\circ} \mathrm{C}\right)$ & $5-10$ & 2 \\
\hline & Cold water enema $\left(12-18^{\circ} \mathrm{C}\right)$, during fasting & 10 & 5 \\
\hline Mud therapy & Full body mud bath & $25-30$ & 1 \\
\hline Massage therapy & Full body massage & 45 & 2 \\
\hline \multicolumn{4}{|l|}{ Diet therapy } \\
\hline Days & Diet- content & & Calorific value/day (K cal) \\
\hline Day-1 & Naturopathic boiled diet $* 3$ times & & $1500-2000$ \\
\hline Day-2 & $\begin{array}{l}\text { Raw diet inclusive of sprouts (green gram and } \\
\text { fruits (papaya/or banana) or vegetable salad (C } \\
\text { and tomato) } * 3 \text { times }\end{array}$ & $\begin{array}{l}\text { ound nut), } \\
\text { rot, cucumber }\end{array}$ & 1500 \\
\hline Day-3 & Fruit or vegetable diet $* 3$ times & & 1000 \\
\hline Day-4, 5 and 6 & Carrot juice $250 \mathrm{ml} * 4$ times daily & & 600 \\
\hline Day-7 & Apple Juice $250 \mathrm{ml} * 4$ times. & & 800 \\
\hline Day-8 & Fruit or vegetable diet $* 3$ times. & & 1000 \\
\hline Day-9 & Fruit or vegetable diet $* 3$ times. & & 1000 \\
\hline \multirow[t]{2}{*}{ Day-10 } & $\begin{array}{l}\text { Raw diet inclusive of sprouts, fruits or vegetab } \\
\text { times. }\end{array}$ & salad *3 & 1000 \\
\hline & & & Duration of practice (min) \\
\hline \multirow{4}{*}{$\begin{array}{l}\text { Yoga therapy } \\
\text { (every day for } 50 \\
\text { minutes) }\end{array}$} & $\begin{array}{l}\text { Asanas: Suryanamaskar, Viparita karani, Mat } \\
\text { Marjariasan, Halasana, Janu Shirsasana }\end{array}$ & asana, & 19 \\
\hline & Instant relaxation technique & & 1 \\
\hline & $\begin{array}{l}\text { Controlled breathing (pranayama): Bhastrika, } \\
\text { Nadi-shodhana }\end{array}$ & apalabhati, & 15 \\
\hline & Relaxation techniques & & 15 \\
\hline
\end{tabular}

Table 2: Baseline comparison of study variables of study group and control group $(n=30)$.

\begin{tabular}{|c|c|c|c|c|c|}
\hline S. no. & Variables & Study group & Control group & T value & P value \\
\hline 1 & Age (years) & $41.4 \pm 7.7$ & $43.4 \pm 7.0$ & -1.068 & 0.290 \\
\hline 2 & Anthropometric variables & & & & \\
\hline $\mathbf{a}$ & Height $(\mathrm{cm})$ & $163.0 \pm 9.4$ & $164.1 \pm 7.2$ & -0.516 & 0.608 \\
\hline b & Body weight (kg) & $87.5 \pm 11.1$ & $85.3 \pm 8.5$ & 0.835 & 0.407 \\
\hline c & BMI $\left(\mathrm{kg} / \mathrm{m}^{2}\right)$ & $32.9 \pm 2.6$ & $31.6 \pm 1.5$ & 2.269 & 0.027 \\
\hline d & $\mathrm{WC}(\mathrm{cm})$ & $95.0 \pm 10$ & $92.6 \pm 8.2$ & 1.004 & 0.319 \\
\hline e & $\mathrm{HC}(\mathrm{cm})$ & $106.1 \pm 8.2$ & $104.8 \pm 6.6$ & 0.696 & 0.489 \\
\hline $\mathbf{f}$ & Waist/hip ratio & $0.89 \pm 0$ & $0.9 \pm 0.1$ & 0.773 & 0.442 \\
\hline 3 & Lipid profile (mg/dl) & & & & \\
\hline $\mathbf{a}$ & TG & $205.3 \pm 30.3$ & $199 \pm 58.9$ & 0.524 & 0.602 \\
\hline b & $\mathrm{TC}$ & $237.1 \pm 29.2$ & $216.4 \pm 32.6$ & 2.595 & 0.112 \\
\hline c & VLDL-C & $21.3 \pm 3.3$ & $30.9 \pm 11.7$ & -4.331 & $0.021 *$ \\
\hline d & LDL-C & $182.1 \pm 28.9$ & $145.7 \pm 35.7$ & 4.334 & 0.172 \\
\hline $\mathbf{e}$ & HDL-C & $33.9 \pm 5.1$ & $39.7 \pm 7.2$ & -3.630 & $0.016^{*}$ \\
\hline 4 & Thyroid profile & & & & \\
\hline $\mathbf{a}$ & $\mathrm{T}_{3}(\mathrm{ng} / \mathrm{dl})$ & $103.4 \pm 26.4$ & $117.8 \pm 20.5$ & -2.361 & 0.082 \\
\hline
\end{tabular}




\begin{tabular}{|llllll|}
\hline S. no. & Variables & Study group & Control group & T value & P value \\
\hline b & $\mathrm{T} 4(\mu \mathrm{g} / \mathrm{dl})$ & $6.4 \pm 1$ & $6.7 \pm 1.1$ & -1.337 & 0.187 \\
\hline C & $\mathrm{TSH}(\mathrm{mU} / \mathrm{l})$ & $9.8 \pm 2.8$ & $10.5 \pm 2.2$ & -1.057 & 0.295 \\
\hline
\end{tabular}

Data expressed is mean \pm SD. Statistical test used: Independent samples t test. *p<0.05. BMI: body mass index; WC: waist circumference; HC: hip circumference; TG: triglycerides; TC: total cholesterol; LDL-C: low density lipoprotein cholesterol; VLDL-C: very low density lipoprotein cholesterol; HDL-C: high density lipoprotein cholesterol; $\mathrm{T}_{3}$ : triiodthyronine, $\mathrm{T}_{4}$ : Thyroxine; TSH: thyroid stimulating hormone; SD: standard deviation.

Table 3: Intergroup comparison of changes in study variables following 10 days of intervention $(n=30)$.

\begin{tabular}{|lllll|l|}
\hline S. no & Variables & $\begin{array}{l}\text { Study group } \\
\text { Pre-post }\end{array}$ & $\begin{array}{l}\text { Control group } \\
\text { Pre-post }\end{array}$ & T value & P value \\
\hline $\mathbf{1}$ & Anthropometric variables & & & & \\
\hline a & Body weight $(\mathrm{kg})$ & $5.8 \pm 1.6$ & $0.29 \pm 1.6$ & 13.085 & $<0.01^{* *}$ \\
\hline $\mathbf{b}$ & BMI $\left(\mathrm{kg} / \mathrm{m}^{2}\right)$ & $0.1 \pm 0.6$ & 12.717 & $<0.01^{* *}$ \\
\hline c & WC $(\mathrm{cm})$ & $2.2 \pm 0.7$ & $1.5 \pm 2$ & 3.128 & $<0.05^{*}$ \\
\hline d & HC $(\mathrm{cm})$ & $3.6 \pm 3.1$ & $1.3 \pm 1.6$ & 3.279 & 0.75 \\
\hline e & Waist/hip ratio & $2.4 \pm 1.2$ & $0.01 \pm 0$ & 1.429 & 0.158 \\
\hline $\mathbf{2}$ & Lipid profile (mg/dl) & $0.01 \pm 0$ & & & \\
\hline a & TG & $20.0 \pm 0$ & $3.8 \pm 51.3$ & 1.734 & $<0.05^{*}$ \\
\hline b & TC & $31.0 \pm 0$ & $-9.2 \pm 19.2$ & 11.454 & $<0.01^{* *}$ \\
\hline c & VLDL-C & $-0.93 \pm 7.1$ & $2.8 \pm 10.2$ & -1.625 & 0.11 \\
\hline d & LDL-C & $37.0 \pm 7.4$ & $-13.2 \pm 24.9$ & 10.602 & $<0.05^{*}$ \\
\hline e & HDL-C & $-5.0 \pm 1.6$ & $1.3 \pm 1.3$ & -2.611 & $<0.05^{*}$ \\
\hline $\mathbf{3}$ & Thyroid profile & & & \\
\hline a & T $(\mathrm{ng} / \mathrm{dl})$ & $-4.5 \pm 11.8$ & $1.8 \pm 14.5$ & -1.854 & 0.69 \\
\hline b & T4 $(\mu \mathrm{g} / \mathrm{dl})$ & $-0.18 \pm 0.8$ & $-0.36 \pm 0.7$ & 0.910 & 0.367 \\
\hline c & TSH $(\mathrm{mU} / \mathrm{l})$ & $0.78 \pm 0.6$ & $0.28 \pm 0.4$ & 3.591 & $<0.05^{*}$ \\
\hline
\end{tabular}

Data expressed is mean $\pm \mathrm{SD}$ of the difference in the variables from pre-test to post test. Statistical test used: Independent samples $\mathrm{t}$ test. ${ }^{*} \mathrm{p}<0.05, * * \mathrm{p}<0.01$. BMI: body mass index; WC: waist circumference; HC: hip circumference; TG: triglycerides; TC: total cholesterol; LDL-C: low density lipoprotein cholesterol; VLDL-C: very low density lipoprotein cholesterol; HDL-C: high density lipoprotein cholesterol; $\mathrm{T}_{3}$ : triiodthyronine, $\mathrm{T}_{4}$ : Thyroxine; TSH: thyroid stimulating hormone; $\mathrm{SD}$ : standard deviation.

Table 4: Changes in values of study variables in study group and control group subjects following intervention.

\begin{tabular}{|c|c|c|c|c|c|c|}
\hline \multirow{2}{*}{ Variables } & \multicolumn{3}{|c|}{ Study group (n=30) } & \multicolumn{3}{|c|}{ Control group (n=30) } \\
\hline & Pre test & Post test & t-value & Pre test & Post test & t-value \\
\hline \multicolumn{7}{|c|}{ Anthropometric variables } \\
\hline Body weight $(\mathrm{kg})$ & $87.5 \pm 11.1$ & $81.7 \pm 10.9 * *$ & 19.657 & $85.3 \pm 8.5$ & $85.1 \pm 8.2$ & 0.979 \\
\hline BMI $\left(\mathrm{kg} / \mathrm{m}^{2}\right)$ & $32.9 \pm 2.6$ & $30.7 \pm 2.4 * *$ & 17.629 & $31.6 \pm 1.5$ & $31.5 \pm 1.4$ & 0.940 \\
\hline $\mathrm{WC}(\mathrm{cm})$ & $95.0 \pm 10$ & $91.4 \pm 9.1$ & 6.345 & $92.6 \pm 8.2$ & $91.1 \pm 9$ & 4.124 \\
\hline $\mathrm{HC}(\mathrm{cm})$ & $106.1 \pm 8.2$ & $103.7 \pm 8.3$ & 11.443 & $104.8 \pm 6.6$ & $103.6 \pm 7.5$ & 4.401 \\
\hline Waist/hip ratio & $0.89 \pm 0$ & $0.88 \pm 0$ & 2.525 & $0.9 \pm 0.1$ & $0.9 \pm 0.1$ & 2.040 \\
\hline \multicolumn{7}{|c|}{ Lipid profile (mg/dl) } \\
\hline TG & $205.3 \pm 30.3$ & $185.3 \pm 30.3 *$ & 23.725 & $199 \pm 58.9$ & $195.3 \pm 55$ & 0.402 \\
\hline TC & $237.1 \pm 29.2$ & $206.1 \pm 29.2 *$ & 15.312 & $216.4 \pm 32.6$ & $225.6 \pm 33.2$ & -2.164 \\
\hline VLDL-C & $21.3 \pm 3.3$ & $22.27 \pm 5.4$ & -0.719 & $30.9 \pm 11.7$ & $28.2 \pm 11$ & 1.479 \\
\hline LDL-C & $182.1 \pm 28.9$ & $145.07 \pm 30^{*}$ & 27.524 & $145.7 \pm 35.7$ & $158.9 \pm 35.7$ & -2.905 \\
\hline HDL-C & $33.9 \pm 5.1$ & $38.9 \pm 5.3$ & -17.144 & $39.7 \pm 7.2$ & $38.5 \pm 11.9$ & 0.532 \\
\hline \multicolumn{7}{|l|}{ Thyroid profile } \\
\hline $\mathrm{T}_{3}(\mathrm{ng} / \mathrm{dl})$ & $103.4 \pm 26.4$ & $107.9 \pm 21.3$ & -2.104 & $117.8 \pm 20.5$ & $116 \pm 14.5$ & 0.679 \\
\hline $\mathrm{T} 4(\mu \mathrm{g} / \mathrm{dl})$ & $6.4 \pm 1$ & $6.5 \pm 0.9$ & -1.240 & $6.7 \pm 1.1$ & $7.1 \pm 0.9$ & -2.833 \\
\hline TSH (mU/l) & $9.8 \pm 2.8$ & $9.0 \pm 2.5^{*}$ & 6.834 & $10.5 \pm 2.2$ & $10.2 \pm 2$ & 3.551 \\
\hline
\end{tabular}

All values are mean \pm SD; pre-test- at $1^{\text {st }}$ day before intervention, post-test-at the end of $10^{\text {th }}$ day. Statistical test used: Student paired $t$ test. *p<0.05, ${ }^{* *} \mathrm{p}<0.01$. BMI: body mass index; WC: waist circumference; HC: hip circumference; TG: triglycerides; TC: total cholesterol; LDL-C: low density lipoprotein cholesterol; VLDL-C: very low density lipoprotein cholesterol; HDL-C: high density lipoprotein cholesterol; T3: triiodthyronine, T4: Thyroxine; TSH: thyroid stimulating hormone; SD: standard deviation. 


\section{DISCUSSION}

The present study was designed to determine the impact of a ten day Naturopathic and yogic intervention on anthropometric variables, serum lipid profile and serum thyroid profile in obese hypothyroid subjects. The results of the present study showed significant changes in the body weight, BMI, WC, triglycerides, total cholesterol, and LDL cholesterol in the subjects of study group.

A previous study showed significant reduction in total cholesterol, LDL and triglycerides, and significant improvement in HDL cholesterol following six months of intense yoga in women suffering from hypothyroidism. ${ }^{20}$ Another study on 20 hypothyroidism women, on 1 month of yoga practice showed significant improvement in the quality of life, and study by Swami et al on 6 months of pranayama practice improved forced expiratory volume in lung function test of women with hypothyroidism. ${ }^{21}$ Previous studies have shown beneficial effects of naturopathy treatments in relation to body weight, lipid profile and blood pressure in obese individuals. Biro et al shown that in obese patients, the body weight and body fat significantly decreased after 2 weeks of sauna therapy. ${ }^{22}$ A study by Masuda et al shows that, repeated sauna therapy improves impaired vascular endothelial function in a patient with coronary risk factors. Sauna therapy significantly decreased urinary 8-epiprostaglandin F2 $\alpha$ levels as a marker of oxidative stress in patients with at least one coronary risk factor. ${ }^{23}$ Following massage therapy to whole body has shown reduction of the subcutaneous fat in subjects with hyperlipidemia. ${ }^{24}$ Studies have proved exposure to short cold or hot water application leads to temperature changes in the skin; there is a temporary increase in blood pressure where the body responds by increasing circulation to the area. Subsequently, this decreases the blood pressure and increases the oxygen consumption in the body which enhances metabolic rate. ${ }^{25}$

Altered TSH levels are the most sensitive indicator of hypothyroidism. ${ }^{9}$ The results of the study showed significant decrease in TSH in study group, which is supported by a randomized controlled trial on 6 months of yoga nidra (yogic relaxation method) practice. ${ }^{26}$

Even though, the results of the present study shows the effectiveness of yoga in improving body weight and BMI, the mechanism underlying weight-related outcomes remains unclear. There are a number of theories which are proposed, including increased energy expenditure, increased mindfulness and body awareness, and reduced stress after yoga practice. ${ }^{27} \mathrm{~A}$ systematic review has shown like other physical activity, physical yoga postures like bhujangasana (cobra pose) and pranayama techniques viz., Bhastrika and Kapalabhati increases oxygen consumption, without maximal exertion. ${ }^{28}$ So, this may led to the reduction in the body weight. Studies have shown that obesity is associated with overstimulation of the hypothalamo-pituitary-adrenal axis (HPA axis) due to chronic stress that alters the diurnal cortisol secretion. Abnormal regulation of the HPA axis and perceived stress dependent cortisol levels are strongly related to perturbations of the endocrine axis. ${ }^{29,30}$ The pranayama, relaxation practices and meditation are known to reduce stress and modulate the hypothalamo-pituitary-adrenal axis. ${ }^{31}$ Similarly, yoga practice might influence the hypothalamo-pituitary-thyroid axis and lead to decrease in serum TSH. Small sample size and short duration of intervention were the limitations of the study.

\section{CONCLUSION}

The improvement in the body weight, BMI, lipid profile and thyroid profile of the obese hypothyroid patients following yogic and naturopathic interventions suggest that it may be considered as an adjuvant therapy for the better management of patients suffering from hypothyroidism.

\section{ACKNOWLEDGEMENTS}

The authors gratefully acknowledge the help of Vice Chancellor, registrar, and the members of the Research department of Rajiv Gandhi University of health Sciences, Karnataka, for funding this project.

Funding: This project is funded by Rajiv Gandhi University of Health Sciences, Karnataka

Conflict of interest: None declared

Ethical approval: The study was approved by the Institutional Ethics Committee

\section{REFERENCES}

1. Chaker L, Bianco AC, Jonklaas J, Peeters RP. Hypothyroidism. Lancet. 2017;390(10101):1550-62.

2. Unnikrishnan AG, Kalra S, Sahay RK, Bantwal G, John M, Tewari N. Prevalence of hypothyroidism in adults: An epidemiological study in eight cities of India. Indian J Endocrinol Metab. 2013;17(4):647-52.

3. Singh P, Singh B, Dave R, Udainiya R. The impact of yoga upon female patients suffering from hypothyroidism. Complement Ther Clin Pract. 2011;17(3):132-4.

4. Marwaha RK, Tandon N, Gupta N, Karak AK, Verma K, Kochupillai N. Residual goitre in the postiodization phase: iodine status, thiocyanate exposure and autoimmunity. Clin Endocrinol (Oxf). 2003;59(6):672-81.

5. Reinehr T. Obesity and thyroid function. Mol Cell Endocrinol. 2010;316(2):165-71.

6. Hoogwerf BJ, Nuttall FQ. Long-term weight regulation in treated hyperthyroid and hypothyroid subjects. Am J Med. 1984;76(6):963-70.

7. Asvold BO, Bjøro T, Vatten LJ. Association of serum TSH with high body mass differs between smokers and never-smokers. J Clin Endocrinol Metab. 2009;94(12):5023-7. 
8. Al-Adsani H, Hoffer LJ, Silva JE. Resting energy expenditure is sensitive to small dose changes in patients on chronic thyroid hormone replacement. J Clin Endocrinol Metab. 1997;82(4):1118-25.

9. Michalopoulou G, Alevizaki M, Piperingos G, Mitsibounas D, Mantzos E, Adamopoulos P, et al. High serum cholesterol levels in persons with 'highnormal' TSH levels: should one extend the definition of subclinical hypothyroidism? Eur J Endocrinol. 1998;138(2):141-5.

10. Cappola AR, Ladenson PW. Hypothyroidism and atherosclero $\neg$ sis. J Clin Endocrinol Metab. 2003;88(6):2438-44.

11. Lindlahr H. Nature cure: philosophy and practice based on the unity of disease and cure. Chicago: Nature Cure Publishing Company; 1922.

12. Techniques and Benefits of Different Modalities of Naturopathy. Available at: http://indianmedicine. nic.in/index3.asp?sslid=262\&subsublinkid=92\&lang $=1$. Accessed on 23 October 2018.

13. Mooventhan A, Shetty GB. Effect of integrative naturopathy and yoga therapies in patient with metabolic syndrome. Int $\mathbf{J}$ Health Allied Sci. 2015;4(4):263-6.

14. Gordon L, McGrowder DA, Pena YT, Cabrera E, Lawrence-Wright MB. Effect of yoga exercise therapy on oxidative stress indicators with end-stage renal disease on hemodialysis. Int $\mathrm{J}$ Yoga. 2013;6(1):31-8.

15. Hegde SV, Adhikari P, Kotian S, Pinto VJ, D’Souza S, D'Souza V. Effect of 3-Month Yoga on Oxidative Stress in Type 2 Diabetes With or Without Complications: A controlled clinical trial. Diabetes Care. 2011;34(10):2208-10.

16. Woodyard C. Exploring the therapeutic effects of yoga and its ability to increase quality of life. Int $\mathbf{J}$ Yoga. 2011;4(2):49-54.

17. Taimini IK: The Science of Yoga. Madras: The Theosophical Publishing House; 1986.

18. Pal A, Srivastava N, Tiwari S, Verma NS, Narain VS, Agrawal GG, et al. Effect of yogic practices on lipid profile and body fat composition in patients of coronary artery disease. Complement Ther Med. 2011;19(3):122-7.

19. Han TS, Sattar N, Lean M. Assessment of obesity and its clinical implications. BMJ. 2006;333(7570):695-8.

20. Nilakanthan S, Metri K, Raghuram N, Hongasandra N. Effect of 6 months intense Yoga practice on lipid profile, thyroxine medication and serum TSH level in women suffering from hypothyroidism: A pilot study. J Complement Integr Med. 2016;13(2):189-93.

21. Swami G, Singh S, Singh KP, Gupta M. Effect of yoga on pulmonary function tests of hypothyroid patients. Indian J Physiol Pharmacol. 2010;54:51-6.

22. Biro S, Masuda A, Kihara T, Tei C. Clinical implications of thermal therapy in lifestyle-related diseases. Exp Biol Med. 2003;228(10):1245-9.

23. Masuda A, Miyata M, Kihara T, Minagoe S, Tei C. Repeated Sauna Therapy Reduces Urinary 8-EpiProstaglandin F2. Jpn Heart J. 2004;45(2):297-303.

24. Adcock D, Paulsen S, Jabour K, Davis S, Nanney LB, Shack RB. Analysis of the effects of the deep mechanical massage in the procine model. Plast Reconstr Surg. 2001;108(1):233-40.

25. Michalsen A, Lu“dtke R, Bu“hring M, Spahn G, Langhorst J, Dobos GJ. Thermal hydrotherapy improves quality of life and hemodynamic function in patients with chronic heart failure. Am Heart J. 2003;146(4):728-33.

26. Rani M, Singh U, Agrawal G, Natu S, Kala S, Ghildiya A. Impact of Yoga Nidra on menstrual abnormalities in female of reproductive age. J Altern Complement Med. 2013;19(12):925-9.

27. Bernstein AM, Bar J, Ehrman JP, Golubic M, Roizen MF. Yoga in the management of overweight and obesity. Am J Lifestyle Med. 2014;8(1):33-41.

28. Tyagi A, Cohen M. Oxygen consumption changes with yoga practices: A systematic review. Evid Based Complement Alternat Med. 2013;18(4):290-308.

29. Rosmond R, Dallman MF, Björntorp P. Stress-related cortisol secretion in men: relationships with abdominal obesity and endocrine, metabolic and hemodynamic abnormalities. J Clin Endocrinol Metab. 1998;83(6):1853-9.

30. Roth B, Creaser T. Mindfulness meditation-based stress reduction: experience with a bilingual innercity program. Nurse Pract. 1997;22(3):150-2.

31. Malhotra V, Singh S, Singh KP, Sharma SB, Madhu SV, Gupta P, et al. Effects of yoga asanas and pranayama in non-insulin dependent diabetes mellitus. Indian J Tradit Know. 2004;3:162-7.

Cite this article as: Shetty GB, Shetty B, Shetty P. Effect of short-term naturopathy and yoga intervention on anthropometric variables, lipid profile and thyroid profile in obese hypothyroid patients: a randomised controlled trial. Int J Basic Clin Pharmacol 2020;9:247-53. 